\title{
The p68 autoantigen characteristic of rheumatoid arthritis is reactive with carbohydrate epitope specific autoantibodies
}

\author{
St Blä $\beta$, Ch Meier, H W Vohr, M Schwochau, Ch Specker, G R Burmester
}

Department of

Medicine III,

Rheumatology and

Clinical Immunology,

Charité University

Hospital, Humboldt

University of Berlin,

Germany

St Blä $\beta$

G R Burmester

Institute for Genetics, Heinrich Heine

University of

Düsseldorf, Germany

Ch Meier

M Schwochau

Institute for

Toxicology,

Pharmacological

Research Centre

Aprath, Bayer AG,

Wuppertal, Germany

$\mathrm{H}$ W Vohr

Department of

Rheumatology,

University Clinics of

Düsseldorf, Germany

Ch Specker

Correspondence to:

Dr S Blä $\beta$, Immunologisch-

Rheumatologisches Labor,

Charité, Tucholskystr 2,

D-10117 Berlin, Germany.

Accepted for publication

4 February 1998

\begin{abstract}
Objective-The autoantigen p68 is a target of autoantibodies as well as autoreactive $T$ cells with a high specificity in rheumatoid arthritis (RA). The binding characteristics of the autoantibodies to their antigen were now analysed biochemically and cytologically.

Methods-Deglycosylation techniques as well as lectin and sugar competition experiments were performed to p68 to discover if the antibodies detected a glycoepitope. Its antigenicity was investigated applying anti-p68 antibodies derived from $R A$ patients in comparison with polyclonal rabbit anti-p68 antibodies. Results-p68 specific antibodies from RA patients did not to bind to p68 that had been deglycosylated by alkaline $\beta$-elimination, $O$-glycosidase or periodate treatment. In contrast, binding of p68 specific antibodies raised in rabbit was unaffected by either deglycosylation protocol. Furthermore, lectins specific for the carbohydrate $\boldsymbol{N}$-acetylglucosamine competed with p68 specific antibodies from $R A$ patients for antigen binding. $\boldsymbol{N}$-acetylglucosamine by itself also competed with patient derived anti-p68 antibodies for p68 binding. Again, rabbit anti-p68 antibodies did not elicit these competitive effects. Applying cytoimmunofluorescence, p68 was present in the cytoplasm or endoplasmic reticulum and also in low abundance on the cell surface. Under heatshock conditions, p68 was detectable in the nucleus.

Conclusions-Autoimmunity to p68 during $R A$ is carried by anti-carbohydrate autoantibodies. The carbohydrate modification of p68 appears to be $\boldsymbol{N}$-acetylglucosamine, which may reflect the regulation of intracellular localisation of the antigen. It is hypothesised that a shift in glycosylation pattern accompanied by an unphysiological localisation of the antigen could trigger antigenicity of p68 during the pathogenesis of RA.

(Ann Rheum Dis 1998;57:220-225)
\end{abstract}

Rheumatoid arthritis (RA) is the most frequent systemic rheumatic disease. The aetiology and pathogenesis of the disease, however, are not well understood and the diagnosis, especially in the early stages of the disease, is often difficult. The rheumatoid factor (RF), by definition a human anti-IgG autoantibody, is the only serological parameter included in a catalogue of criteria for the diagnosis of RA. ${ }^{1}$ It is present in approximately $70 \%$ of RA patients, but also in up to $20 \%$ of patients with other systemic disorders ${ }^{2}$; it even occurs in apparently healthy people in whom the RF assay is adjusted so that up to $5 \%$ of them are positive. ${ }^{3}{ }^{4}$ The RF in RA patients is often an agalactosylated IgG terminating in $N$-acetyl glucosamine (N-GlcNAc), rather than galactose or sialic acid. ${ }^{5-8} \beta-1,4-$ galactosyltransferase that catalyses the addition of galactose to the oligosaccharide chains on this molecule has been shown to undergo a variety of normal and disease associated changes. ${ }^{9}$ The latter may contribute to the pathological processes in RA. Monoclonal rheumatoid factors have been described that detect the agalactosylated IgG better than the normal form. ${ }^{10}$ For mouse anti-collagen II agalactosyl-IgG, but not for the normally glycosylated antibodies, pathogenicity in collagen induced arthritis (CIA) has been described. ${ }^{11}$ An IgG preparation for passive transfer of collagen induced arthritis proved more effective when first digested with $\beta$-galactosidase to increase the level of the agalactosyl IgG glycoform. It is thus evident that the glycosylation status of autoantigens is of importance in the autoimmune response.

Previously, anti-p68 antibodies have been described by our group in $66 \%$ of RA patients, but not in healthy controls or patients with other autoimmune diseases as a possible aid for an improved diagnosis of the disease. ${ }^{2}$ Furthermore, the impact of these antibodies in the pathogenesis of RA could be underlined by the demonstration of p68 specific T cells. ${ }^{12}$ They were detected in $67 \%$ of RA patients. Family specific anti-HLA DP, DQ and DR antibodies were capable of increasing stimulation of the p68 specific response of some RA patients when added to $T$ cell proliferation assays. This was regarded indicative of the presence of class II restricted p68 specific suppressive $\mathrm{T}$ cells otherwise inhibiting the proliferation of p68 specific helper $\mathrm{T}$ cells. The p68 antigen shows an isoelectric point of 5.1 and a relative molecular mass of 68000 . The antigen that had originally been identified in the synovium and is probably ubiquitously expressed in humans, is detectable also in mouse, but not in insect cells. To further analyse p68, affinity purified RA patient derived anti-p68 antibodies were applied for immunoscreening of various human cDNA expression vector libraries. We analysed why these autoantibodies failed to detect specific clones in these experiments. One possible explanation was that the 
patients' antibodies were directed to a carbohydrate epitope.

Various examples of anti-carbohydrate antibodies can be given, especially when occurring in certain disease states. Thus, in rats monoclonal antibodies have been described as being specific for carbohydrate epitopes on Trichinella spiralis, which are protective against the parasite by causing rapid expulsion. ${ }^{13}$ In chronic Chagas' disease, anti- $\alpha$-galactosyl antibodies are found to be lytic to Trypanosoma cruzi. The smallest reactive residue is $O$ - linked Gal $1-3$ Gal $\beta 1-4$ GlcNAc. The carbohydrates are reactive with Chagas', but not with healthy anti-Gal antibodies, indicating that $T$ cruzi O-linked oligosaccharides are highly immunogenic under infectious conditions. ${ }^{14}$ The unusual finding here is that $O$-linked GlcNAc is reported with further glycosidic modifications for the first time. In humans suffering from diseases like RA, Crohn's disease, tuberculosis, sarcoidosis or erythema nodosum leprosum, autoantibodies reactive with O-GlcNAc have been described. ${ }^{15}$ The possibility is discussed that the anti-carbohydrate immune responses could also evoke cross reacting anti-peptide autoantibodies.

In this study we have demonstrated that the patient antibodies were directed to a carbohydrate epitope that is very probably not expressed in prokaryotic expression systems $(E$ coli). p68 was purified using patient antibodies to raise a specific antiserum in rabbits. This p68 specific rabbit antiserum is compared with the human antiserum with respect to carbohydrate epitope binding.

\section{Methods}

ANTIBODIES

Serum samples containing p68 specific antibodies were obtained from RA patients attending our rheumatology unit.

HeLa proteins were separated by SDSPAGE as described. Immunisation was performed injecting the neutralised p68 containing polyacrylamide matrix (approximately $1 \mu \mathrm{g}$ of p68 as estimated by Bradford quantification $\left.{ }^{16}\right)$. For the first boost, two dimensionally purified p68 antigen contained in the neutralised and ground poly-acrylamide matrix (as described ${ }^{2}$ ) was applied. For the second boost, ConA binding fraction was separated on SDS-PAGE, and the eluted material from the p68 band was injected. Antibodies obtained by this protocol were directed against protein epitopes and could thus function as controls in the various deglycosylation experiments described below.

The secondary antibodies were FITC conjugated IgG sheep anti-human or sheep antirabbit (all classes each) antibodies from Wellcome, England and used because they demonstrated the lowest number of cross reactions. Incubation was for three hours at room temperature at a 1:100 dilution as recommended. Immunoreactions were visualised at $492 \mathrm{~nm}$ wave length.
ENZYMES

All enzymes were purchased from Boehringer/ Mannheim, Germany. $O$-glycosidase from Diplococcus pneumoniae is described as an $O$-glycopeptide-endo-D-galactose-GalNAchydrolase. Neuraminidase from Arthrobacter ureafaciens catalyses the hydrolysis of terminal $N$ - or $O$-acyl neuraminic acids in $\alpha 2-3, \alpha 2-6$ or a2-8-bonds in, for example, glycoproteins. $\mathrm{N}$-glycosidase F from Flavobacterium meningioseptum is a glycan-asparagine-amidase and cleaves off all forms of asparagine-bound $N$-glycans from glycolipids or $N$-proteins.

\section{PATIENTS}

Serum samples of nine RA patients fulfilling the ACR criteria ${ }^{1}$ were obtained after consent. All samples were anti-p68 positive, two of them were rheumatoid factor negative.

\section{LECTINS}

Lectins from the DIG Glycan Differentiation Kit, Boehringer/Mannheim, Germany or from Sigma. GNA (Galanthus nivalis agglutinin) were used and directed to terminal Man $\alpha(1-3)-, \alpha(1-6)-$ or $\alpha(1-2)-$ linked to Man; SNA (Sambucus nigra agglutinin), directed to sialic acid (SA) $\alpha(2-6)$ linked to Gal; MAA (Maackia amurensis agglutinin), directed to SA $\alpha(2-3)$ linked to Gal; PNA (peanut agglutinin), directed to Gal $\beta(1-3)$ GalNAc without further substituents; DSA (Datura stramonum agglutinin), directed to Gal $\beta(1-4)$ linked to GlcNAc and GlcNAc. Sigma: ConA (Concanavalin A), directed to $\alpha$-D-mannopyranoside, $\alpha$-D/Lglucopyranoside, GlcNAc, $\alpha / \beta$-D-arabinofuranoside, $\alpha / \beta$-fructofuranoside and also small hydrophobic molecules ${ }^{17}$; DBA (Dolichus biflorus agglutinin), directed to $\alpha-$ GalNAc; RCA $_{\mathrm{I}}$ (Ricinus communis agglutinin), directed to $\beta$-linked Gal; UEA-I (Ulex europaeus agglutinin), directed to $\alpha$-L-fucose; WGA (wheat germ agglutinin), directed to GlcNAc, $\beta(1-4)$ linked oligomers of GlcNAc and SA.

Protein preparation was performed as described elsewhere. ${ }^{2}$

\section{LECTIN BINDING AND COMPETITION}

EXPERIMENTS

Lectin binding was performed applying the DIG (digoxigenin) glycan differentiation kit, which was performed as described in the product literature. Lectin competition was carried out with the same concentrations of lectin as suggested for binding studies. Lectins were then preincubated on western blots for one hour at room temperature. Subsequently, antibodies were incubated overnight. Immunoreactivity was tested with FITC conjugated secondary antibodies from Wellcome, Germany, and visualised at $492 \mathrm{~nm}$.

\section{CARBOHYDRATE COMPETITION}

Carbohydrates were preincubated with antibodies for three hours at room temperature. Sugar concentrations were $1 \mathrm{M}, 100 \mathrm{mM}$, and $10 \mathrm{mM}$. Carbohydrates remained present during incubation of antibodies with blotted protein material overnight. 
ALKALINE $\beta$-ELIMINATION

Total HeLa protein $(40 \mu \mathrm{g})$ or purified p68 or blot strips of SDS-PAGE separations of total proteins were incubated at $37^{\circ} \mathrm{C}$ for 16 hours in either $4 \mathrm{ml}$ water or $5 \mathrm{mM}$ or $10 \mathrm{mM}$ solutions of sodium hydroxide. Samples were then adjusted to $\mathrm{pH} 7$, precipitated and subjected to SDS-PAGE and immunoblotting. Blot strips were directly incubated with RA or control antibodies. Detection of the immunoreaction was carried out with FITC conjugated secondary antibodies.

\section{ENZYMATIC DEGLYCOSYLATION}

HeLa proteins were separated by SDS-PAGE and blotted as described. ${ }^{2}$ Blot strips were blocked in a buffer containing $1.1 \% \mathrm{NP} 40$ and $2 \% \mathrm{BSA}$ and incubated for 15 minutes at $75^{\circ} \mathrm{C}$ in $1 \mathrm{ml}$ of a $1 \%$ SDS solution. Subsequently, a 10 -fold excess of NP-40 was adjusted with an NP-40 buffer and again incubated for $15 \mathrm{~min}$ utes at $75^{\circ} \mathrm{C}$. This step is mandatory for enzyme activity, which would be destroyed in the presence of a vast excess of SDS. After cooling down the solution to $37^{\circ} \mathrm{C}, 5 \mathrm{mU}$ $O$-glycosidase and $40 \mathrm{mU}$ of neuraminidase or $1 \mathrm{U}$ of $\mathrm{N}$-glycosidase $\mathrm{F}$ were added and incubated for 16 hours at $37^{\circ} \mathrm{C}$. Then, after a washing step, immunoreaction was performed.

\section{PERIODATE TREATMENT}

Blot strips of total HeLa protein were blocked in the above described buffer and incubated with $10 \mathrm{mM}$ sodium periodate and $100 \mathrm{mM}$ sodium acetate for two hours at room temperature at $\mathrm{pH} 5.2$ in the dark. Controls were incubated in sodium acetate only.

CYTOIMMUNOFLUORESCENCE

HeLa cells were grown on microscope slides overnight at $37^{\circ}$, eventually heatshocked for one hour at $42^{\circ}$, and denatured in $3.5 \%$ paraformaldehyde and $0.15 \%$ NP40. Primary (anti-p68) and secondary antibodies were incubated for one hour at room temperature.

\section{Results}

DEGLYCOSYLATION EXPERIMENTS

Based on the observation that RA anti-p68 antibodies failed to detect clones in immunoscreening experiments, deglycosylation experiments were performed to consider whether these antibodies detected a glycoepitope on p68. Alkaline $\beta$-elimination specifically removes $O$-linked carbohydrate residues from glycoproteins. ${ }^{18}$ Either total HeLa proteins, purified p68 or blot strips of HeLa proteins separated by SDS-PAGE were subjected to mild base catalysed $\beta$-elimination. Immunoreactivity with the RA antibodies was abolished partially at sodium hydroxide concentrations of $5 \mathrm{mM}$ and completely at concentrations as low as $10 \mathrm{mM}$ (fig 1). Eight other anti-p68 positive RA serum samples exhibited the same pattern of immunoreactivity (data not shown). No correlation to the presence of rheumatoid factors was observed ( $p>0.5$; Fisher's exact test).

Rabbit control antibodies specific for proteinacous epitopes of $\mathrm{p} 68$ were not affected by either treatment. This proved that incubation at

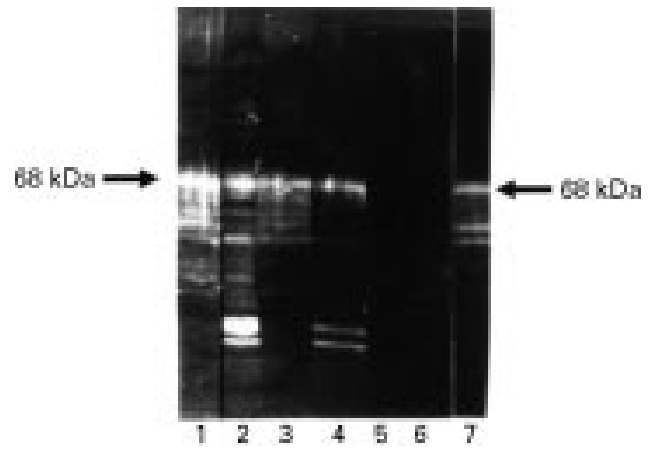

Figure 1 Alkaline $\beta$-elimination. HeLa protein western blot. Lanes 1 and 2 preincubated in water, 3-5 in $5 \mathrm{mM}$ $\mathrm{NaOH}, 6-7$ in $10 \mathrm{mM} \mathrm{NaOH}$. Subsequent incubation with anti-p68-positive $R A$ serum $(2,4,6)$, anti-p68-negative human control serum (5), anti-p68-positive rabbit serum $(1,3,7)$ and anti-p68-negative control serum. Detection with FITC conjugated secondary antibody. p68 was detected by the $R A$ serum antibody after incubation with water (2) and with 5 $\mathrm{mM} \mathrm{NaOH}$ (4), but not after incubation with $10 \mathrm{mM}$ $\mathrm{NaOH}$ (6). p68 was detectable by the rabbit serum antibody even after $10 \mathrm{mM} \mathrm{NaOH}$ treatment (7).

mild hydroxide conditions did not degrade protein epitopes of p68. Also enzymatic cleavage of sugars was investigated applying $O$-glycosidase and $\mathrm{N}$-glycosidase $\mathrm{F}$, both of which contained no protease activity. In some $\mathrm{O}$-glycosidase experiments, neuraminidase was co-incubated to potentially remove sialic acids and to improve accessibility to potential $O$-glycosidase cleavage in case of high sialylation. $O$-glycosidase treatment of blot strips with p68 or solubilised total protein containing p68 abolished immunoreactivity with the RA, but again not with rabbit anti-p68 antibodies (fig 2). Coincubation of neuraminidase with $O$-glycosidase had no apparent effect on immunoreactivity (data not shown). $\mathrm{N}$-glycosidase $\mathrm{F}$ treatment had no effect on either antibody (fig 2). No gel shift exceeding 1-2 k was visible when deglycosylated $\mathrm{p} 68$ protein was subjected to SDS-PAGE (10\%, $12 \mathrm{~cm}$ length).

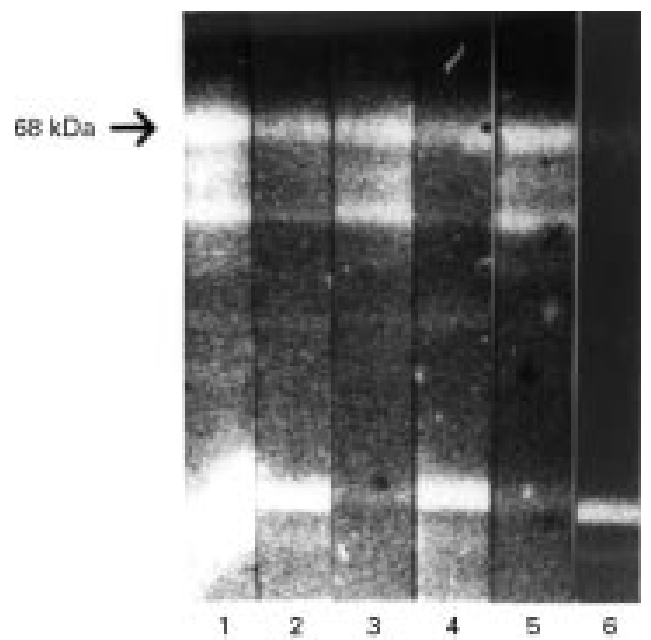

Figure 2 O-glycosidase. HeLa protein western blot. Lanes 1 and 2 preincubated with water, $3+4$ with $N$-glycosidase $F$, 5-6 with O-glycosidase. Subsequent incubation with anti-p68-positive $R A$ serum $(2,4,6)$ or anti-p68-positive rabbit serum. Detection with FITC conjugated secondary antibody. $p 68$ was detectable by the $R A$ serum antibody after incubation with water and with $N$-glycosidase $F$ and not after incubation with $O$-glycosidase (5).p68 was detectable by the rabbit serum antibody even after treatment with O-glycosidase (6). 


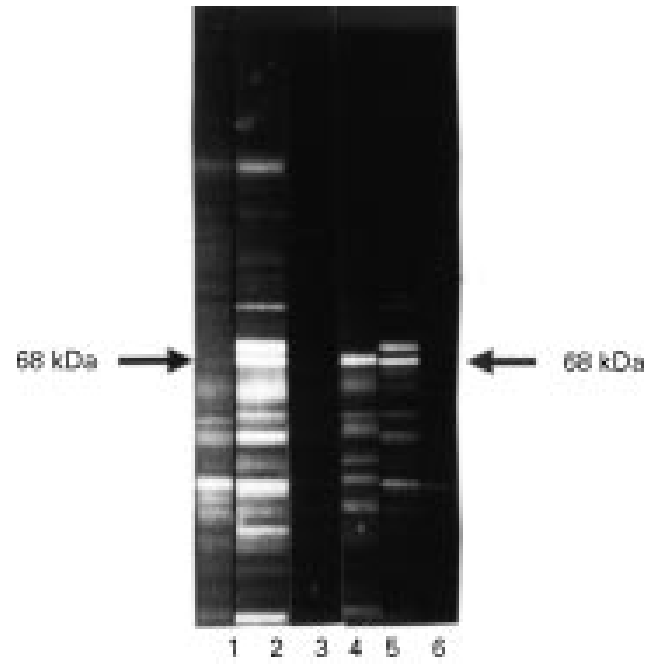

Figure 3 Periodate treatment. HeLa protein western blot. Lanes 1-3 preincubated with sodium periodatelacetate and 4-6 with sodium acetate for two hours at room temperature. Subsequent incubation with anti-p68-positive $R A$ serum (1 $+4)$, anti-p68-positive rabbit serum $(2+5)$ and anti-p68-negative control serum $(3+6)$. Detection with FITC conjugated secondary antibody. After treatment with periodate, $p 68$ was detected by the rabbit (2), but not by the $R A$ serum antibody (1).

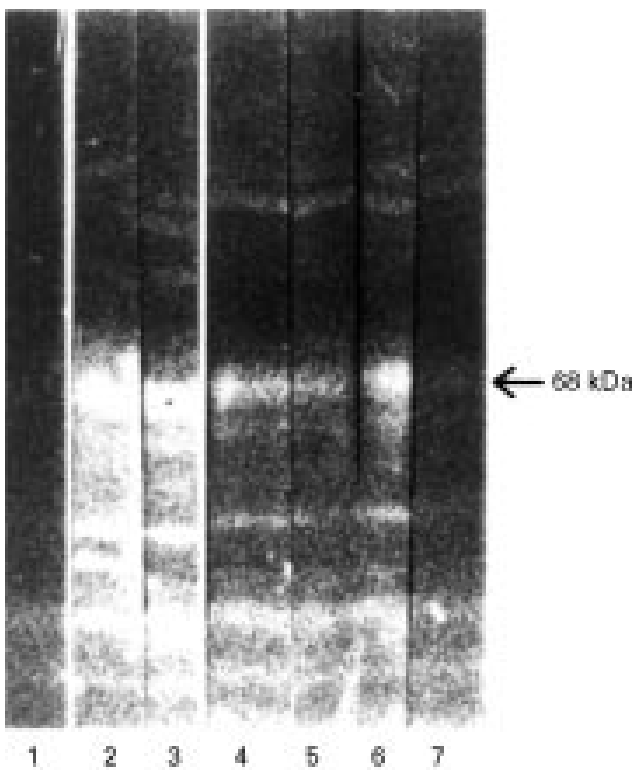

Figure 4 Lectin competition. HeLa protein western blot. Lane 1 incubated with anti-p68 negative control serum, 2 with anti-p68 positive $R A$ serum, 3 with anti-p68 positive rabbit serum; $4+5$ with $D B A$ and $6+7$ with $W G A$ over night. Subsequent incubation with anti-p68 positive $R A$ serum $(5+7)$ and with anti-p68 positive rabbit serum (4 $+6)$. Detection with FITC conjugated secondary antibody. The lectin $W G A$, but not $D B A$ competed with the $R A$ serum anti-p68 antibody for binding to $p 68(7,5)$. Neither lectin could compete with the rabbit anti-p68 antibody (6, 4).

CARBOHYDRATE OXIDATION

General oxidation and thereby destruction of potential carbohydrate epitopes at concentrations of $10 \mathrm{mM}$ periodate also abrogated p68 reactivity with RA, but not with rabbit antibodies (fig 3).

LECTIN BINDING AND COMPETITION EXPERIMENTS To further analyse the nature of the glycosylation of p68, various lectins were tested for antigen binding. WGA, DSA, and ConA did

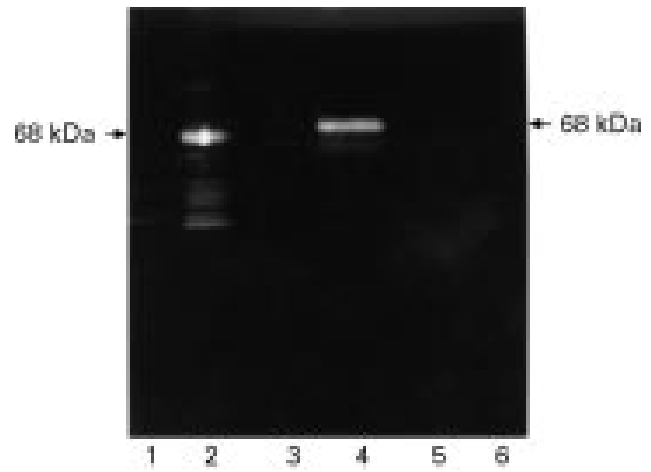

Figure 5 ConA binding. HeLa protein western blot. Lanes 1 and 2 total HeLa protein, 3+4 ConA column eluate, 5+6 flow through fraction. Incubation with anti-p68-positive $R A$ serum $(2,4,6)$ and anti-p68-negative human control serum. Detection with FITC conjugated secondary antibody. 668 could by detected in the eluate, but not in the flow through fraction $(4,6)$.

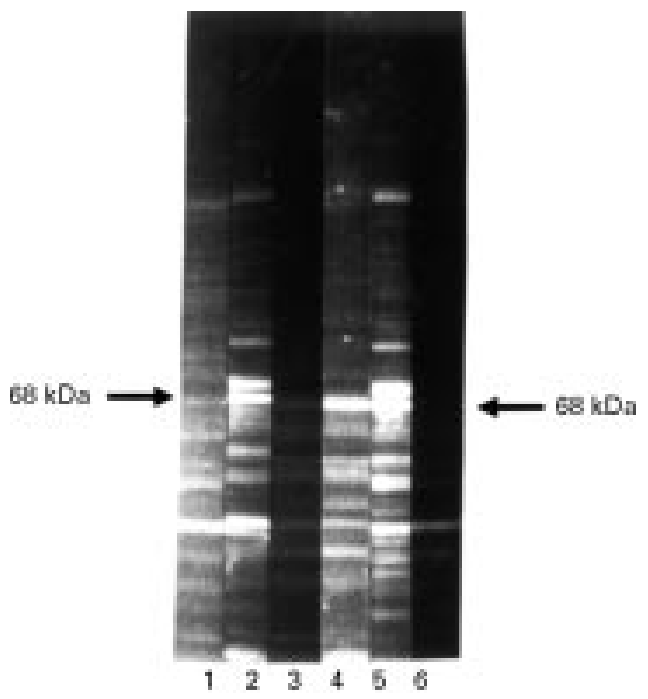

Figure 6 Carbohydrate competition. HeLa protein western blot. Preincubation with GlcNAc (1-3) and with water (4-6). Subsequent incubation with anti-p68-positive $R A$ serum $(1,4)$, anti-p68-positive rabbit serum $(2,5)$ and anti-p68-negative control serum $(3,6)$. Detection with FITC conjugated secondary antibody. GlcNAc could compete with the $R A$, but not with the rabbit serum anti-p68 antibody for binding to $p 68(1,2)$.

bind to the antigen, while GNA, SNA, MAA,

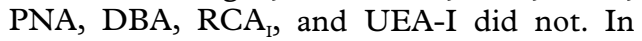
competition experiments the first three lectins were able to compete with the antibody for antigen binding. After initial incubation of the antigen with lectin, immunoreactivity was abrogated with the human, but not with the rabbit p68-specific serum (fig 4). This did not apply to the other lectins, which again had no effect. HeLa proteins were separated by a ConA sepharose column, applying a lectin that is known to bind also $N$-acetylglucosamine (GlcNAc). p68 could be detected in the eluate but not in the flow through fraction (fig 5).

CARBOHYDRATE COMPETITION EXPERIMENTS Finally, we considered whether a single sugar could compete with p68 for binding of RA antibodies. GlcNAc and (glucosamine) GlcN competed at high (1 M) but not at low $(0.1 \mathrm{M})$ sugar concentrations, while all other carbohydrates tested (methyl- $\alpha-\mathrm{D}$ - 


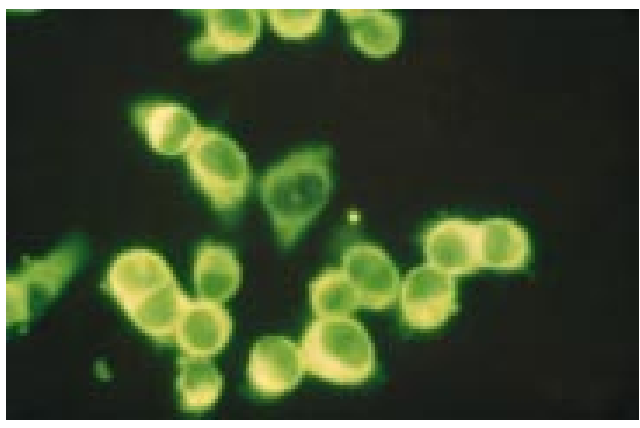

Figure 7 Cytoimmunofluorescence on HeLa cells. HeLa cells denatured in $3.5 \%$ paraformaldehyde and $0.15 \%$ NP40 reacted with human anti-p68 antibodies. Detection using FITC conjugated secondary antibodies. $1 \mu \mathrm{m}$ in nature equals $3 \mathrm{~cm}$ on the picture.

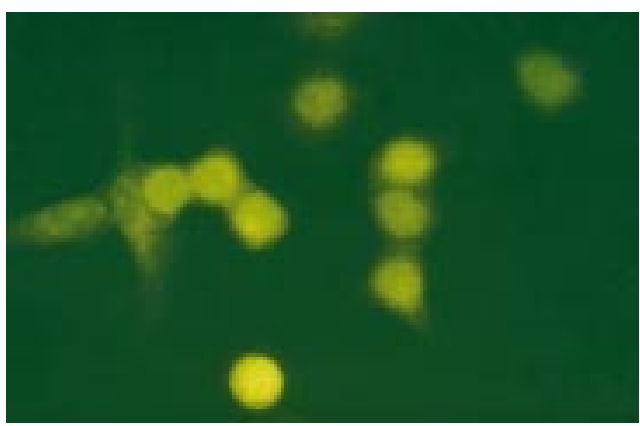

Figure 8 Cytoimmunofluorescence on heatshocked HeLa cells. HeL a cells incubated at $42^{\circ} \mathrm{C}$ for one hour, denatured in $3.5 \%$ paraformaldehyde and $0.15 \%$ NP40 reacted with human anti-p68 antibodies. Detection using FITC conjugated secondary antibodies. 1 m in nature equals 3 cm on the picture.

mannopyranoside, $\mathrm{D}(+)$-mannose, $\alpha-\mathrm{D}(+)-$ glucose, $\alpha-\mathrm{L}(-)$-fucose) had no effect (fig 6 ). Again these results were not obtained when applying rabbit anti-p68 antibodies.

CYTOIMMUNOFLUORESCENCE

Applying cytoimmunofluorescence on HeLa cells, p68 was visible in the cytoplasm or endoplasmic reticulum under physiological conditions (fig 7). Upon heatshock of HeLa cells to $42^{\circ} \mathrm{C}$ the antigen was detected in the nucleus (fig 8). Furthermore, the antigen was also detectable in low amounts on the cell surface (data not shown).

\section{Discussion}

Autoantigen p68 has been detected as a target of RA specific autoantibodies ${ }^{2}$ and $T$ lymphocytes. ${ }^{12}$ In this study, we demonstrated that the antigen is glycosylated and that the carbohydrate is at least part of the epitope recognised by the anti-p68 antibodies derived from RA patients.

Alkaline $\beta$-elimination specifically allows for the cleavage of $O$-linked sugars at concentrations up to $200 \mathrm{mM}$ sodium hydroxide. ${ }^{2}$ There was a complete loss of the sugar at concentrations as low as $10 \mathrm{mM}$, at which alkaline protein degradation is unlikely to occur to a significant degree. No signs of degradation could be detected by comparing protein staining or the amount of protein with or without treatment. The low molecular material that is stained on the immunoblot is not caused by alkaline degradation as it also occurs without this treatment. It is, however, material reactive with other serum antibodies that are not present after purification of anti-p68 antibodies. Nevertheless, specific or preferential cleavage of the p68 protein could not completely be ruled out. Therefore, enzymatic deglycosylation was performed that led to identical results. Loss of immunoreactivity was not caused by the sticking of the enzyme to its sugar substrate and thereby covering a putative protein epitope. Enzyme substrate complexes are separated by SDS-PAGE and a putatively covered epitope will be accessible on western blots again. Thus, for this particular antigen, mild base catalysed $\beta$-elimination on blot strips proved to be a simple deglycosylation method in combination with carbohydrate specific antibodies and might find a broader field of applications.

The lectins that were able to compete with the RA antibody for antigen binding all have the specificity for GlcNAc in common. To analyse if the RA antibodies recognised a carbohydrate containing epitope and to rule out the possibility of conformational changes of p68 being responsible for the differences observed between RA and non-RA antibodies, competition experiments with sugar derivatives were performed. GlcNAc as well as GlcN could compete with the antigen for binding. This in itself is remarkable as it seems that the antibody recognises an epitope consisting of only a single sugar residue, although the finding of antiGlcNAc antibodies, for instance, is not unprecedented. ${ }^{15}$ A protein epitope is the area of an antigen that is covered by the antigen binding site of an antibody (the paratope) and generally consists of approximately 15 amino acids. We thus conclude that the RA anti-p68 antibodies also recognise proteinacous or other carbohydric parts of p68, or both, but that the sugar is a critical determinant. This also applies to the anti-GlcNAc antibodies described by Rook $^{20}$ and Shikhman. ${ }^{15}$ Anti-p68 antibodies derived from RA patients seem to recognise a mixed carbohydrate-protein-epitope of p68. This is confirmed by the finding that only carbohydrate concentrations from $1 \mathrm{M}$ on were capable of competition. These experiments were performed on western blots and only semi-quantitation was possible. It can be estimated from the undetectable gel shift after deglycosylation of p68 that its modification is no larger than five sugar residues. The observation that no change in immunoreactivity was visible after neuraminidase treatment may also argue against modification with sialic acid. It is thus probable that GlcNAc may be a major part of the epitope. GlcNAc is a very common modification of proteins and not specific for p68. The strikingly high disease specificity of anti-p68 antibodies is thus very probably caused by the p68 protein, namely proteinaceous parts of the carbohydrate dominated epitope. Why this structure becomes a target of an autoimmune reaction during RA may well be an unusual modification in time or location, or both, of this particular antigen. GlcNAc is very probably not directly linked to Ser/Thr in p68, but via further carbohydrates. 
The shift of compartments of the p68 antigen upon heatshock implies a regulatory role of mono-O-GlcNAc residues comparable to that seen for many proteins such as the small heatshock protein $\alpha-\mathrm{B}$ crystallin. ${ }^{20}$ Ser-mono-OGlcNAc versus Ser-phosphate are known as a switch for various molecules with respect to activation or localisation of these proteins. ${ }^{21}$ Discussing a modification of p68 with mono$O$-GlcNAc though, is in conflict with the cleavage specificity of $\mathrm{O}$-glycosidase for Ser/ Thr-Galß1-3GalNAc and could only be explained by a widened specificity of the $O$-glycosidase, which also detects and cleaves Ser/Thr-mono-O-GlcNAc bonds. To analyse the carbohydrate composition and sequence, complete sugar release of highly purified p68 antigen and subsequent HPLC analysis of the carbohydrate will be necessary.

The fact that peptides can mimic carbohydrate epitopes or vice versa, especially in autoimmune conditions, ${ }^{22}{ }^{23}$ may fuel the idea of molecular mimicry in the pathogenesis of autoimmune disorders such as RA. Especially, when crossreactivity with autoantibodies occurs that are directed to cytoskeletal protein ${ }^{22}$ and keratin. ${ }^{23}$ Interestingly, anti-keratin antibodies could be induced when immunising $\mathrm{BALB} / \mathrm{c}$ mice with GlcNAc-conjugated BSA but not with BSA alone. Nevertheless, for the RA anti-p68-carbohydrate epitope antibodies no mimicking or crossreactive peptide epitope is known so far, and we were unable to detect such peptide stretches by immunoscreening with autoantibodies.

In this study it is shown that the RA patient anti-p68 antibodies are directed against a carbohydrate epitope. Although rabbits were immunised with native and thus glycosylated p68-antigen, antibodies were derived that reacted with proteinacous parts of the antigen only. One possible explanation is that antibody production against the carbohydrate epitope of p68 may be harmful to the animal and is abrogated by $\mathrm{B}$ cell tolerance. The generation of anti-carbohydrate antibodies to p68 may be of significance for the pathomechanism of the disease. In this respect, variations in $\beta-1,4$ galactosyltransferase are believed to contribute to pathogenesis in rheumatic diseases and a hypothesis is suggested, whereby the disease is associated with the dysregulation of an integrated glycosylation network, comprising galactosylation and anti-carbohydrate specific antibodies. $^{24}$ Agalactosylated antigens are $^{2}$ known to be associated with autoimmune disorders: agalactosyl IgG is frequently found in RA, Crohn's disease, tuberculosis, sarcoidosis, and erythema nodosusum leprosum..$^{25-27}$ Immunising mice with a defined genetic background will help in answering the question whether or not p68 can be pathogenic in an animal system. Further study is needed to consider whether anti-GlcNAc antibodies directed against p68 have any any relation to those that are directed to IgG.

The technical assistence of Silke Mauelshagen is gratefully acknowledged. Supported by a grant from the Deutsche acknowledged. Supported by a grant
1 Arnett FC, Edworthy SM, Bloch DA, McShane DJ, Fries $\mathrm{JF}$, Cooper NS, et al. The American Rheumatism Assocciation 1987 revised criteria for the classification rheumatoid arthritis. Arthritis Rheum 1988;31:315-24.

2 Bläß St, Specker Ch, Lakomek HJ, Schneider EM, Schwochau $M$. Novel $68 \mathrm{k}$ autoantigen detected by rheumatoid arthritis (RA) specific autoantibodies. Ann Rheum Dis 1995;54:355-60.

3 Waaler E. On the occurence of a factor in human serum activating the specific agglutination of sheep blood corpuscles. Acta Pathol Microbiol Scand 1940;17:172-88.

4 Rose HM, Ragan Ch, Pearce E, Lipman MD. Differential agglutination of normal and sensitized sheep erythrocytes by sera of patients with rheumatoid arthritis. Proc Natl Acad Sci USA 1948;68:1-6.

5 Isenberg DA. Humoral immunity and glycosylation abnormalities in rheuamtoid arthritis. Clin Exp Rheumatol 1995;13 (suppl 12):S17-20.

6 Rademacher TW, Mizouchi T, Tanguchi T, Matsuuta K, Taakeuchi F, Nagano Y, et al. Association of rheumatoid arthritis and primary osteoarthritis with changes in the glycosylation pattern of total serum IgG. Nature 1985;316: $452-7$

7 Kobata A. Function and pathology of the sugar chains of human immunoglobulin G. Glycobiology 1090;1:5-8

8 Parekh RB, Dwek RA, Sutton DJ, Fernandes DL, Leung A, Stanworth D, et al. Methyl-a-D-mannopyranoside, mannooligosaccharides and yeast mannans inhibit development of rat adjuvans arthritis. J Rheumatol 1993;20:673-7.

9 Alavi A, Axford J. Beta 1,4-galactosyltransferase variations in rheumatoid arthritis. Adv Exp Med Biol 1995;376:18592 .

10 Bonagura VR, Artandi SE, Davidson A, Randen I, Agostino, Thompson K, et al. Mapping studies reveal unique epitopes on IgG recognized by rheumatoid arthritisderived monoclonal rheumatoid factors. J Immunol derived monoclonal

11 Rademacher TW, Williams P, Dwek RA. Agalactosyl glycoforms of IgG autoantibodies are pathogenic. Proc Natl Acad Sci 1994;91:6123-7.

12 Blä $\beta$ St, Haferkamp C, Specker C, Schwochau M, Schneider M, Schneider EM. Rheumatoid arthritis: autoreactive $\mathrm{T}$ cells recognising a novel $68 \mathrm{k}$-autoantigen. Ann Rheum Dis 1997;56:317-22.

13 Ellis LA, Reason AJ, Morris HR, Dell A, Iglesias R, Ubeira FM, Appleton JA. Glycans as targets for monoclonal antibodies that protect against Trichinella spiralis. Glycobiology 1994;4:585-92.

14 Almeida IC, Ferguson MAJ, Shikhman S, Travassos LR. Lytic anti- $\alpha$-galactosyl antibodies from patients with chronic Chagas' disease recognize novel O-linked oligosacchronic Chagas disease recognize novel O-linked oligosacanchored glycoproteins of Trypanosoma cruzi. Biochem J anchored glycoprotein

15 Shikhman AR, Greenspan NS, Cunningham MW. Cytokeratin peptide SFGSGFGGGY mimics $N$-acetyl- $\beta-\mathrm{D}-$ glucosamine in reaction with antibodies and lectins, and includes in vivo anti-carbohydrate antibody response. J Immunol 1994;153:5593-606.

16 Bradford MM. A rapid and sensitive method for the quantization of microgram quantities of protein using the principle of protein-dye-binding. Anal Biochem 1976;72:24854.

17 So LL, Goldstein IJ. Protein-carbohydrate interactions. Carbohydr Res 1969;10:213-44.

18 Beeley JG. Glycoprotein and proteoglycan techniques. In: Burdon RH, van Knippenberg PH, eds. Laboratory techniques in biochemistry and molecular biology. Amsterdam: techniques in biochemistry

19 Kumpel BM, Rademacher TW, Rook GA, Williams PJ, Wilson IB. Galactosylation of human IgG monoclonal anti-D produced by EBV-transformed B-lymphoblastoid cell lives is dependent on culture method and affects Ftc receptormediated functional activity. Hum Antibodies Hybridomas 1994;5:143-51

20 Roquemore EP, Chevrier MR, Cotter RJ, Hart GW. Dynamic O-GlcNAcylation of the small heat shock protein alpha B-crystallin. Biochemistry 1996;35:3578-86.

21 Chou TY, Dang CV, Hart GW. Glycosylation of the c-Myc transactivation domain. Proc Natl Acad Sci USA 1995;92: $4417-21$.

22 Shikhman AR, Greenspan NS, Cunningham MW. A subset of mouse monoclonal antibodies cross-reactive with cytoskeletal proteins and group A streptococcal M proteins recognizes N-acetyl- $\beta$-D-glucosamine. J Immunol 1993; 151:3902-13.

23 Shikhman AR, Cunningham MW. Immunological mimicry between $\mathrm{N}$-acetyl- $\beta$-D-glucosamine and cytokeratine peptides. J Immunol 1994;152:4375-87.

24 Alavi A, Axford J. Evaluation of beta 1,4galactosyltransferase in rheumatoid arthritis and its role in the glycosylation network with disease. Glycoconj J 1995;12:206-10.

25 Rademacher TW, Williams P, Dwek RA. Agalactosyl glycoforms of IgG autoantibodies are pathogeneic. Proc Natl Acad Sci USA 1994;91:6123-7.

26 Bond A, Alavi A, Axford JS, Bourke BE, Bruckner FE, Kerr $\mathrm{MA}$, et al. A detailed lectin analysis of IgG glycosylation, demonstrating disease specific changes in terminal galactose and $\mathrm{N}$-acetylglucosamine. J Autoimmun 1997;10:7785 .

27 Bodman KB, Hutchings PR, Jeddi PA, Delves PJ, Rook GA, Sumar $\mathrm{N}$, et al. IgG glycosylation in autoimmune-prone strains of mice. Clin Exp Immunol 1994;95:103-7. 